\title{
Adiantum (Pteridaceae) in Brazil: Key to the species and illustrations
}

\author{
Jefferson Prado ${ }^{1,2}$ \& \& Regina Y. Hirai ${ }^{1}$ (1) \\ ${ }^{1}$ Instituto de Botânica, Herbário SP, C.P. 68041, CEP 04045-972, São Paulo, SP, Brasil. \\ ${ }^{2}$ Universidade Estadual Paulista, Instituto de Biociências, Letras e Ciências Exatas, Departamento de Zoologia \\ e Botânica, Rua Cristóvão Colombo, 2265, CEP 15054-000, São José do Rio Preto, SP, Brasil. \\ "Corresponding author: Jefferson Prado,e-mail: jprado.01@uol.com.br
}

PRADO, J., Hirai, R.Y. Adiantum (Pteridaceae) in Brazil: Key to the species and illustrations. Biota Neotropica 20(4): e20201119. https://doi.org/10.1590/1676-0611-BN-2020-1119

\begin{abstract}
Adiantum is a Pantropical genus of ferns, monophyletic, and has about 225 species. It can be recognized by the indusia with veins, bearing sporangia directly on the underside of its reflexed tissue. About 110 species occur in the Neotropical region and 65 of them are reported to Brazil. Among them, 64 are native species and occur mainly in the Amazon Rainforest, Caatinga, Central Brazilian Savanna, and in the Brazilian Atlantic Rainforest. Among the species that occur in Brazil, 16 are endemic and they represent $25 \%$ of the total. This paper presents a key to identify the 63 native species of Adiantum in Brazil, excluding the hybrid one. Illustrations of some morphological features, as well as of all species are also presented to help in the process of identification.
\end{abstract}

Keywords: Diversity; endemic species; ferns; flora of Brazil; identification.

\section{Adiantum (Pteridaceae) no Brasil: chave para as espécies e ilustrações}

Resumo: Adiantum é um gênero Pantropical de samambaias, monofilético e com cerca de 225 espécies. Pode ser reconhecido pelos indúsios com nervuras e esporângios formados diretamente sobre a face inferior do seu tecido reflexo. Aproximadamente 110 espécies ocorrem na região Neotropical e 65 delas são registradas para o Brasil. Entre elas, 64 são espécies nativas e ocorrem principalmente na Floresta Amazônica, Caatinga, nas vegetações abertas do Brasil Central e na Floresta Atlântica Brasileira. Entre a espécies que ocorrem no Brasil, 16 são endêmicas e elas representam $25 \%$ do total. Este trabalho apresenta uma chave para identificação das 63 espécies nativas de Adiantum no Brasil, excluindo o híbrido. Também são apresentadas ilustrações de alguns caracteres morfológicos, bem como de todas as espécies para ajudar no processo de identificação.

Palavras-chave: Diversidade; espécies endêmicas; flora do Brasil; identificação; samambaias. 


\section{Introduction}

Adiantum L. is monophyletic, with ca. 225 species, and is the second biggest genus of the family Pteridaceae (PPG I 2016), behind only Pteris L. with $250 \mathrm{spp}$. Adiantum has a Pantropical distribution, occurring mainly in forests as terrestrial plants. About 110 species are Neotropical.

Recently, Adiantum has been a target of several investigations, including also molecular data to access the evolution of the group and its relationship, and some Brazilian species were sampled for these works. For example, Hirai et al. (2016) and Hirai \& Prado (2019) investigated the group of $A$. raddianum C. Presl and concluded that the group of $A$. poiretii Wikstr. is the most closely related and they can be separated morphologically by the shape of the indusium (reniform in A. raddianum group and oblong in the $A$. poiretii group). This important result is also strongly supported by the molecular data indicating that the species of $A$. poiretii group differ from the $A$. raddianum group by a unique deletion of 66 nucleotides, at positions 288-353 in the chlN gene alignment.

Huiet et al. (2018) addressed a global study for the genus Adiantum, corroborating the monophyletism of the $A$. raddianum group (sensu Hirai et al. 2016) and also showing that the reconstructions of leaf blade architecture revealed remarkable convergent evolution across multiple clades for nearly all leaf forms. Leaves once-pinnate, usually with rachises proliferous at tips define a clade (the philippense clade). Simple leaves (very rare in Adiantum) occur in three distinct clades (davidii, philippense, and peruvianum). Most taxa have leaves that are more than once-pinnate and only a few of these (in the formosum and pedatum clades) exhibit the distinct pseudopedate form. The data about distribution for each studied species show that most species (75\%) are restricted to only one of six major biogeographical regions in the World. In this study (Huiet et al. 2018), 48 of the sampled species (ca. 30\% of the total) are endemic to South America. This study showed that the previous infra-generic classification for Adiantum failed to compose natural group of species based only on morphological aspect because there are several homoplastic characters.

According to the Flora of Brazil online 2020 (Prado \& Hirai, in preparation), there are 65 species occurring in Brazil, 64 of them are native, 16 species are endemic ( $25 \%$ of the total), including one that has a hybrid origin (A. xmoranii J. Prado). Adiantum peruvianum Klotzsch is largely known as cultivated.

The genus itself can be easily identified by the indusia with veins, bearing sporangia directly on the underside of its reflexed tissue (Prado et al. 2017). But the identification of its species is a challenge, especially to the non-expert on ferns.

The main objective of the current work is to present a key for the identification of the recognized species in Brazil (except for the hybrid species), accompanied by illustrations for all taxa, which can be a useful tool for experts and students of ferns.

\section{Material and Methods}

All species included in the present key have been recognized in the treatment of the genus Adiantum for Flora of Brazil online 2020 (Prado \& Hirai, in preparation) (http://floradobrasil.jbrj.gov.br/reflora/ listaBrasil/PrincipalUC/PrincipalUC.do).

Most of this species appeared previously cited for Brazil since the previous papers involving the genus published by Prado \& Sylvestre (2010), Prado (2015), and Prado et al. (2015).
The key is based on the external morphology of the plants and there is no need to use any additional feature of the anatomical part of the organisms for their identification.

To observe the hairs and scales accurately and thus identify species of Adiantum with the key provided below, it is necessary to have a dissecting microscope with at least $30 \mathrm{x}$ and a strong light source. In some species, the hairs become modified as glands, such as in $A$. dawsonii Lellinger \& J. Prado or are protected by the revolute indusia and in both cases their visualization is difficult.

Most of the morphological terms used in the key follow Lellinger (2002). And author abbreviations of scientific names follow Pichi Sermolli (1996).

The endemic species of Adiantum to Brazil appear marked with an asterisk in the key.

Some photos to illustrate this work were provided by the following persons: Michel Boudrie (MB, Adiantum adiantoides (J. Sm.) C. Chr., A. glaucescens Klotzsch, A. leprieurii Hook., A. lucidum (Cav.) Sw., A. paraense Hieron., A. serratodentatum Willd., A. tetraphyllum Willd., A. villosum L.), Fernando Matos (FM, A. diphyllum (Fée) Maxon), Gabriel Moulatlet (GM, A. paraense, A. tomentosum Klotzsch), Gabriela Zuquim (GZ, A. cinnamomeum Lellinger \& J. Prado, A. dolosum Kunze, A. glaucescens, A. humile Kunze, A. obliquum Willd., A. pectinatum Kunze ex Baker, A. terminatum Kunze ex Miq., A. tomentosum), Júlio N. Carauta (JN, A. argutum Splitg.), Hanna Tuomisto (HT, $A$. cinnamomeum, A. cajennense Willd. ex Klotzsch, A. terminatum), Michael Sundue (MS, A. capillus-veneris L.), Nathan Smith (NS, $A$. multisorum A. Samp.), Paulo Labiak (PL, A. discolor J. Prado), Robbin Moran (RM, A. macrophyllum Sw., A. villosum), and the others were taken by the present authors. Additionally, drawings are also presented to illustrate the species.

\section{Results}

Adiantum can be recognized by terete, blackish to castaneous stipes, rachises, and costae, and sporangia borne on the false indusium (i.e., not on the laminar surface below it); also characterized by scales borne at rhizome apices and stipe bases; laminae monomorphic (sterile and fertile laminae similar in morphology), pinnate (rarely undivided) to more divided, sometimes forked or pedate; veins free or rarely anastomosing without included free veinlets; linear epidermal idioblasts (false veins) present or not between the true veins; sori formed on the recurved laminar margins (false indusia), on the veins, paraphyses (i.e., hairs among the sporangia) absent (Prado et al. 2017a).

The main characters used here to recognize the species group are the pattern of venation regular anastomosing veins (forming regular areoles without free veinlets included), irregularly anastomosing (not forming regular areoles and also lacking free veinlets included), or veins free; the veins ending into teeth or ending between teeth at sterile margins of the pinnae/pinnules; rhizome very long-creeping (i.e., cord-like), long-creeping (nodose or not nodose), and short-creeping (generally nodose); indument of the rachises, pinnae, and pinnules (glabrous or with hairs or scales, or both); pattern of the frond division (varying from pinnate to 2-5-pinnate), form of the pinnae/pinnules and indusia. Another important aspect to recognize species is the fact that the pinnae/pinnules/segments are articulate or not (i.e., continuous). In the articulate species, the dark color of the stalk stops at the base of the 
Key to the Adiantum species in Brazil

pinnae/pinnules/segments and, when they are continuous, the color is ending into their laminar tissue. There are some species that present fronds forked one to several times and they are easy to be recognized by this feature.
To facilitate the use of the key, illustrations of some morphological features (Figure 1) and for all species (Figures 2-13) are presented after the key. Some of these illustrations are not from Brazilian specimens but show the morphology of the treated species.

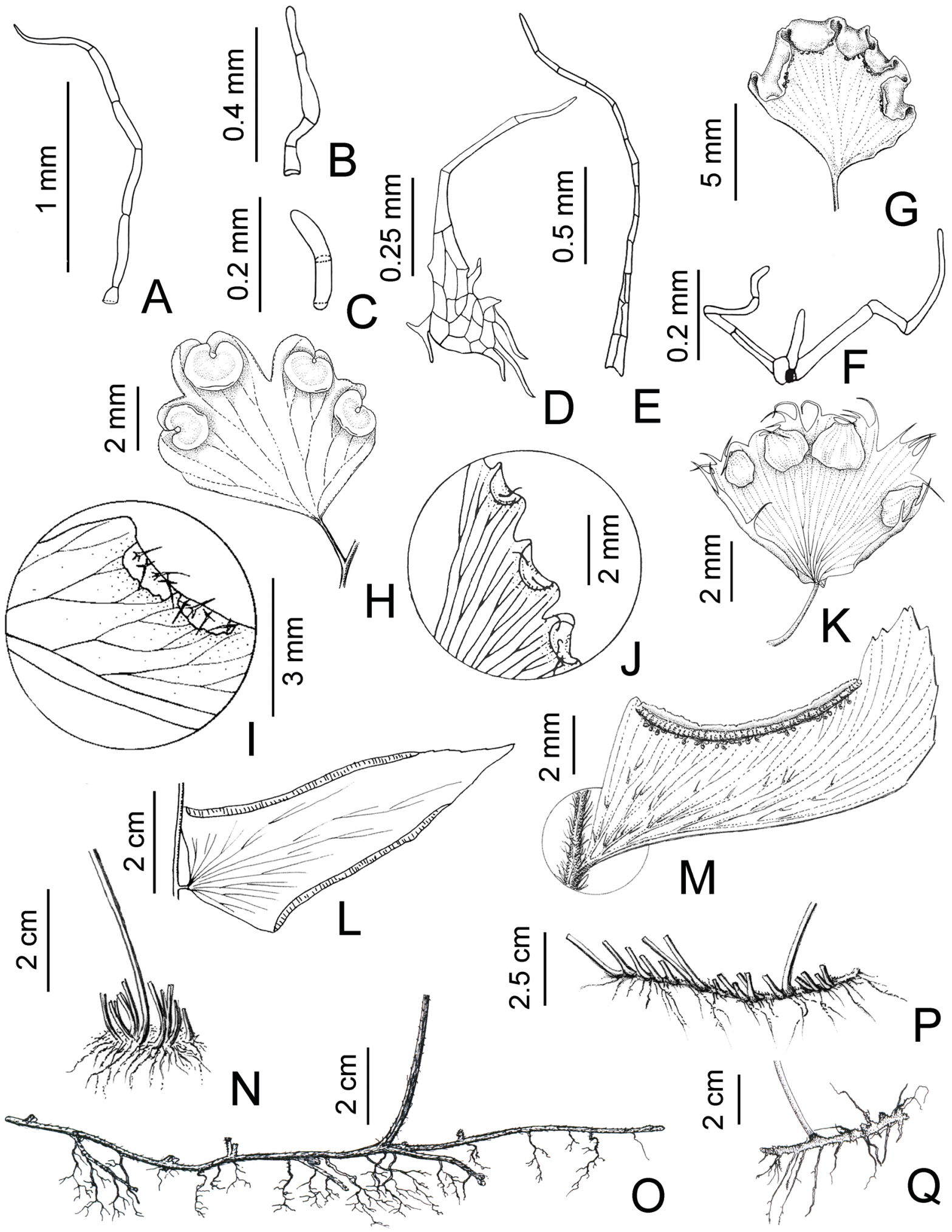

Figure 1. Morphological characters of Adiantum: A. Long-hair. B, C. Short-hairs. D. Lanceolate scale, with pectinate base. E. Linear scale. F. Arachnoid scale. G. Oblong and glabrous indusia. H. Reniform-rounded and glabrous indusia. I. Oblong and scaly indusia. J. Lunate and pubescent (with short-hairs) indusia. K. Lobate-rounded and glabrous indusia. L. Linear and glabrous indusia. M. Linear-arcuate and glabrous indusium. N. Short-creeping rhizome. O. Very long-creeping (cord-like) rhizome. P. Long-creeping and nodose rhizome. Q. Long-creeping rhizome. 

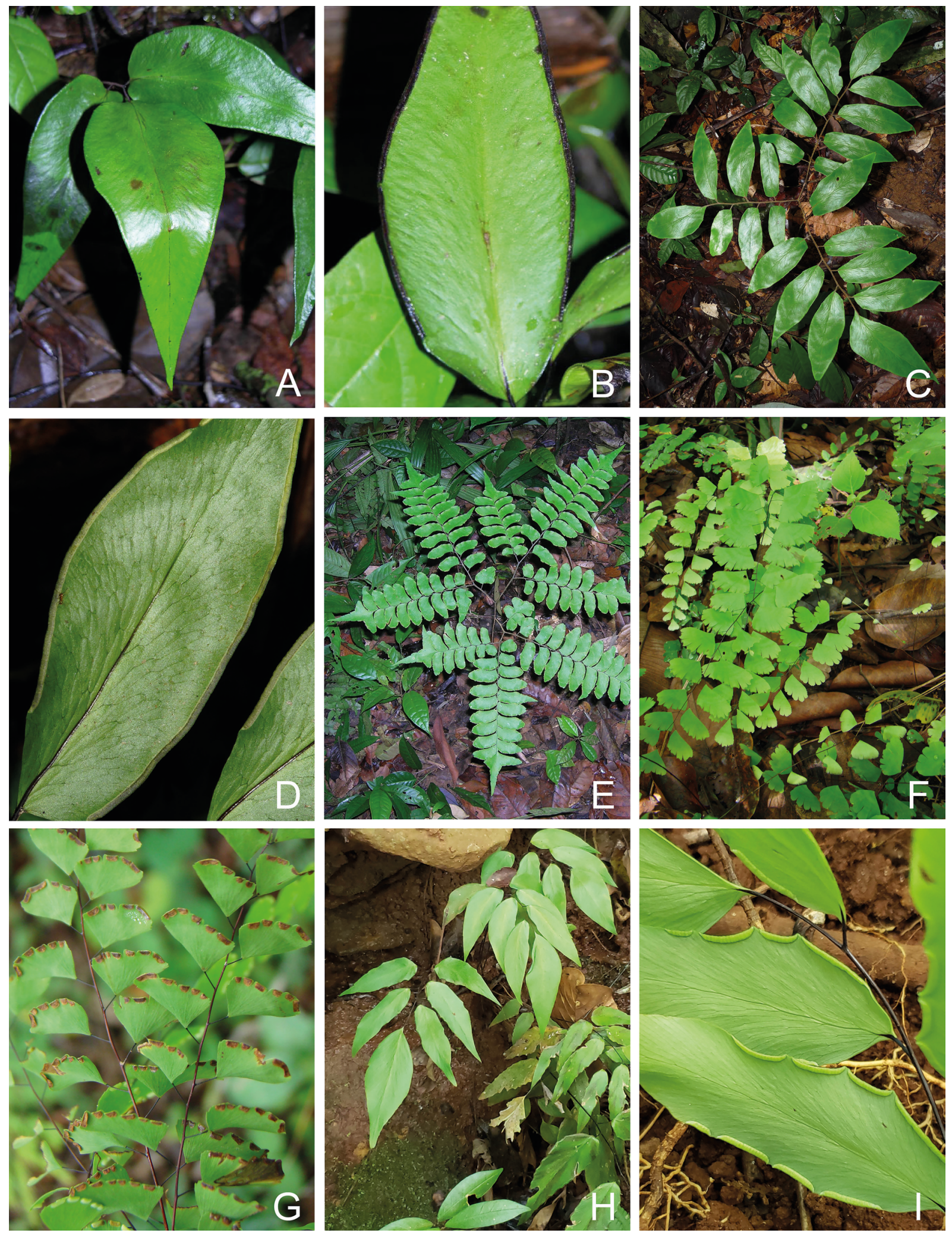

Figure 2. Adiantum species: A-B. A. diphyllum, A. Habit. B. Pinna abaxially (photos: FM). C-D. A. adiantoides, C. Habit. D. Sori (photos: MB). E. A. leprieurii, habit (photo: MB). F-G. A. deflectens, F. Habit. G. Pinnules abaxially. H-I. A. platyphyllum, H. Habit. I. Young sori. 

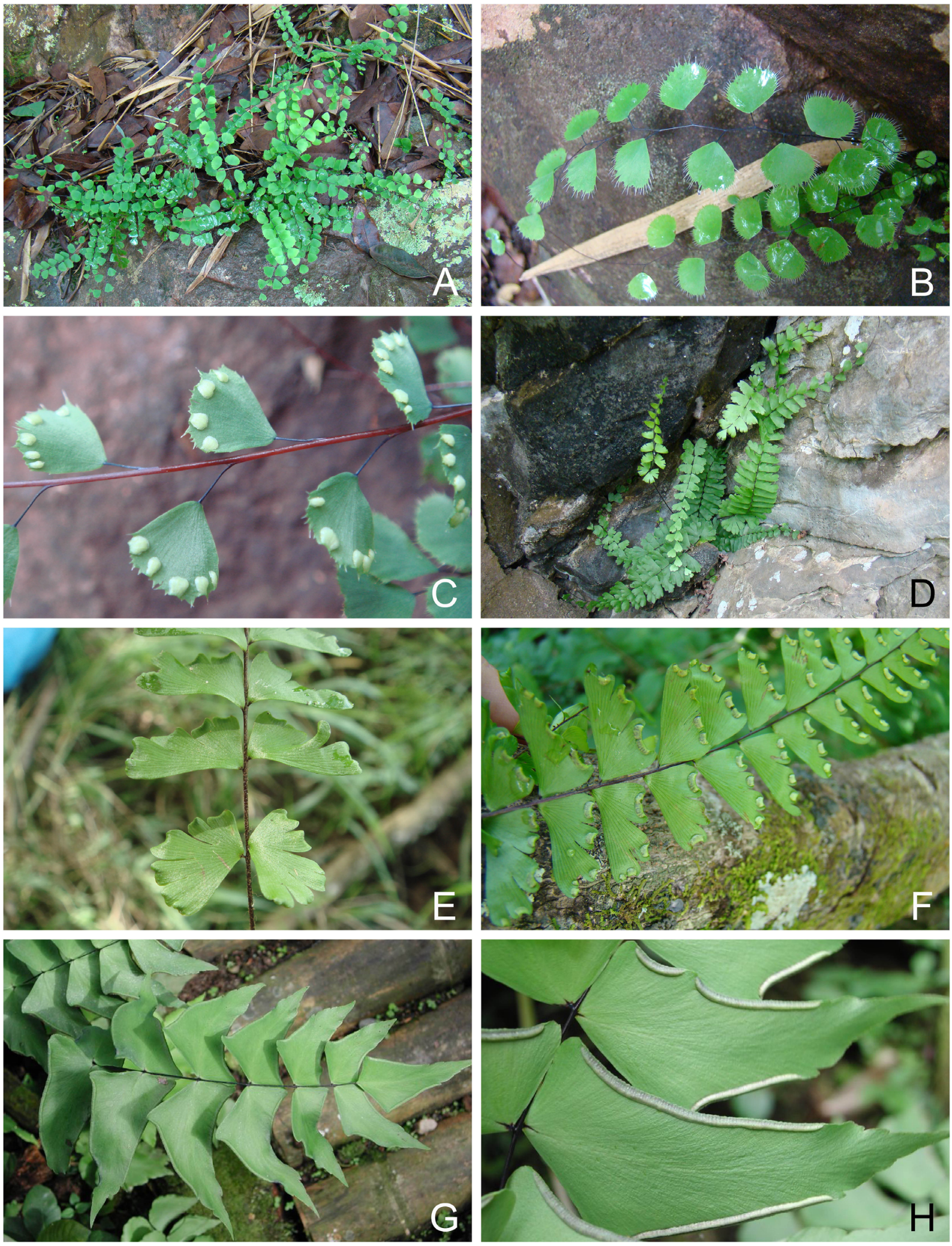

Figure 3. Adiantum species: A-C. A. delicatulum, A. Habit. B. Sterile fronds. C. Sori. D-F. A. calcareum, D. Habit. E. Proximal pinnae. F. Pinnae abaxially. G-H. A. macrophyllum, G. Fertile frond. H. Sori (photos: RM). 

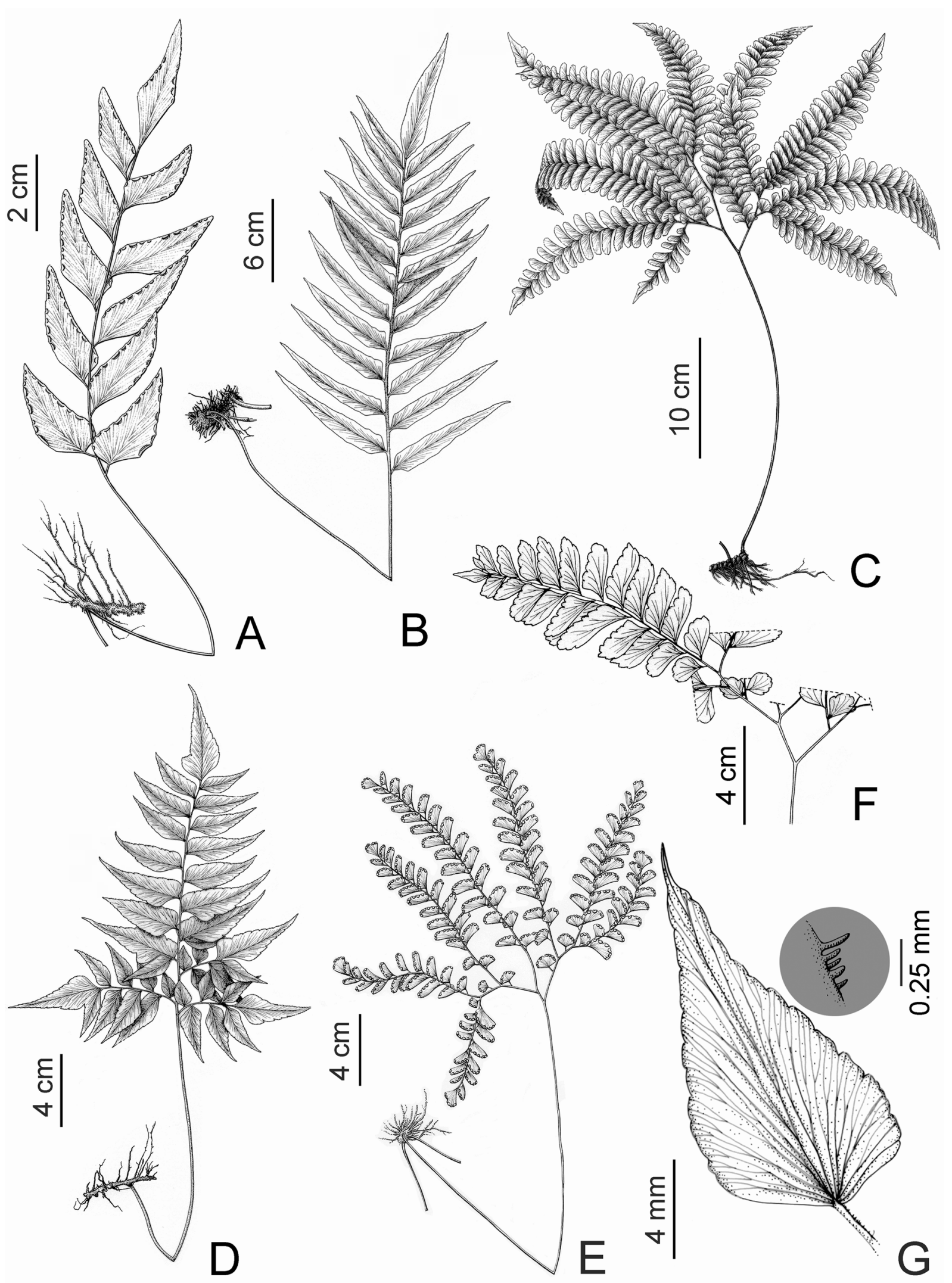

Figure 4. Adiantum species: A. A. nudum, habit. B. A. scalare, habit. C. A. lindsaeoides, habit. D. A. poeppigianum, habit. E. A. patens, habit. F. A. ornithopodum, part of a frond. G. A. papillosum, pinnule and detail of the rachis's hairs. 

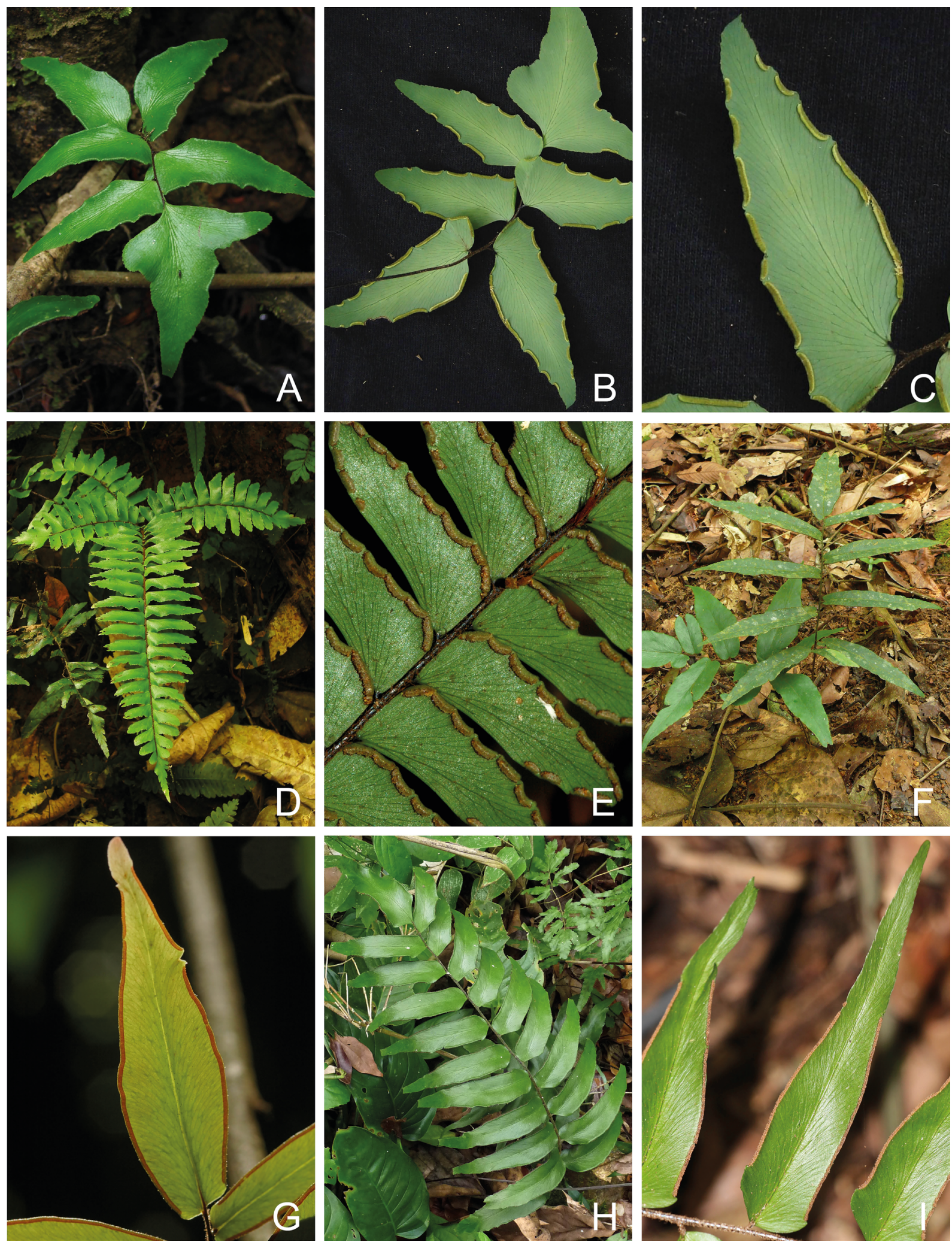

Figure 5. Adiantum species: A-C. A. petiolatum, A. Habit. B. Pinnae abaxially. C. Sori. D-E. A. obliquum, D. Habit. E. Sori (photos: GZ). F-G. A. dolosum, F. Habit. G. Sori (photos: GZ). H-I. A. lucidum, H. Frond. I. Sori (photos: MB). 

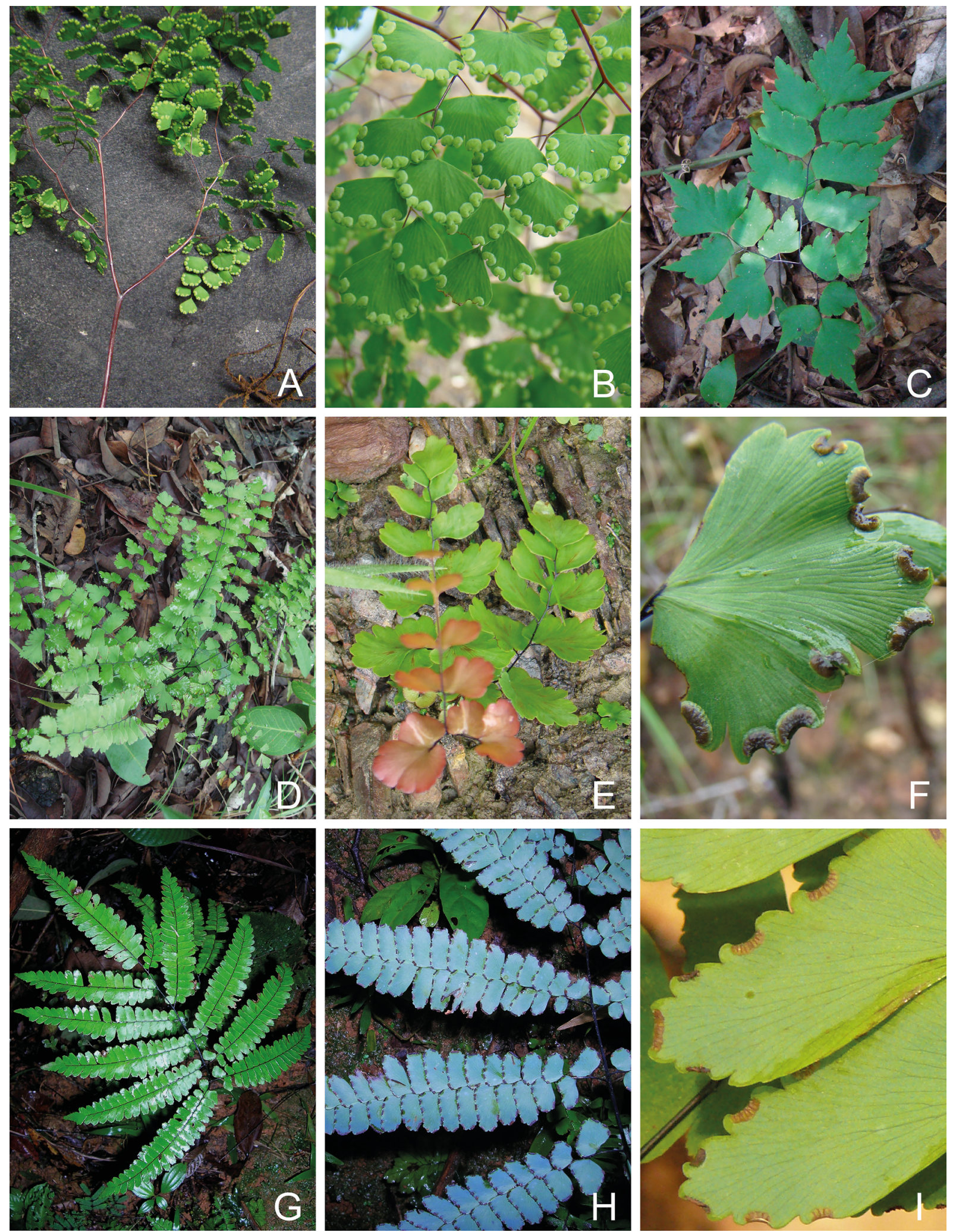

Figure 6. Adiantum species: A-B. A. pseudotinctum, A. Frond. B. Pinnules abaxially. C. A. pentadactylon, Habit. D-F. A. sinuosum, D. Habit. E. Young plant. F. Sori. G-I. A. glaucescens, G. Frond. H. Pinnules abaxially. I. Sori (photos: MB). 
Key to the Adiantum species in Brazil
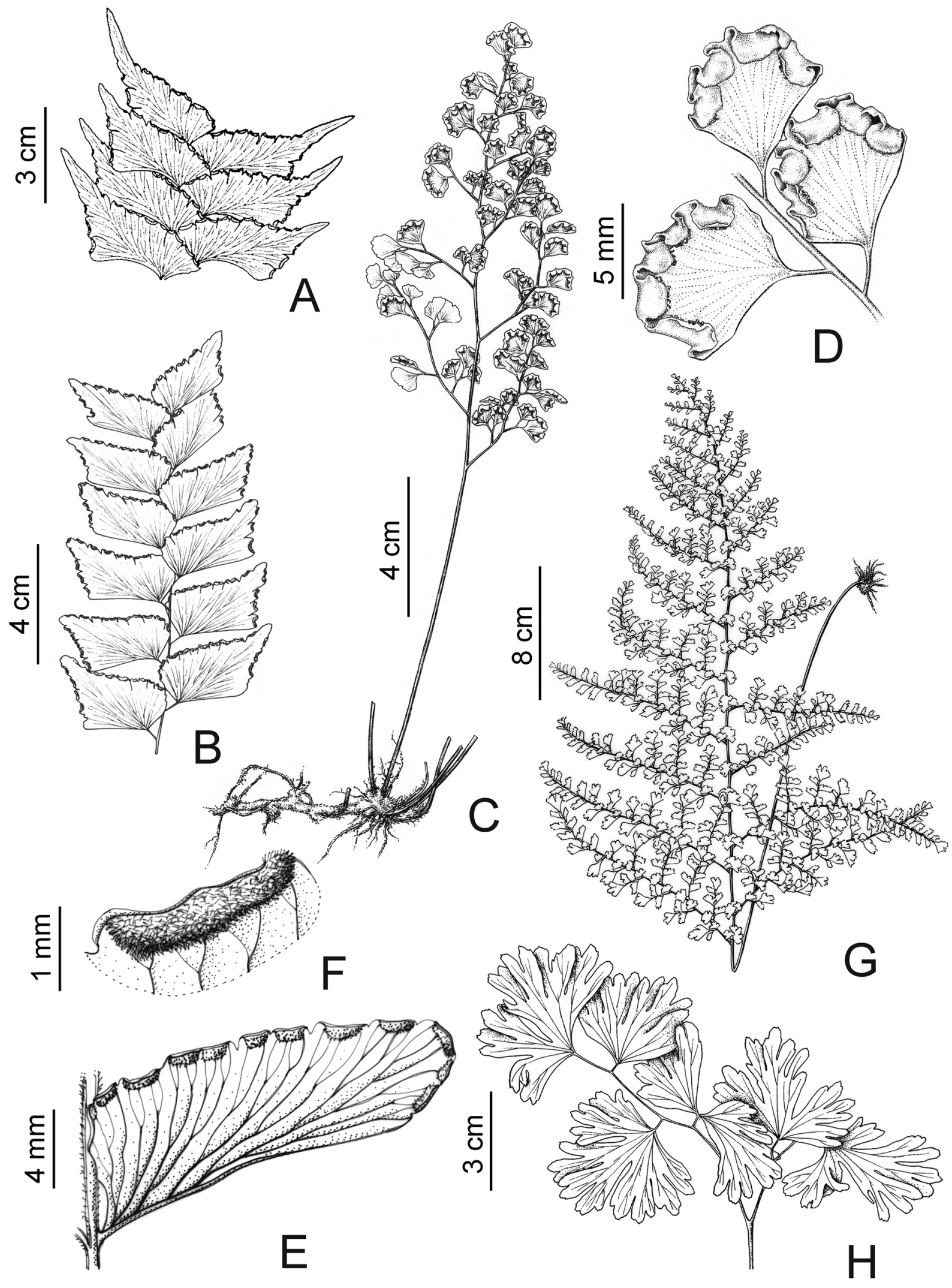

Figure 7. Adiantum species: A. A. mynsseniae, pinnules. B. A. mathewsianum, pinnules. C-D. A. poiretii. C. Habit. D. Indusia. E-F. A. curvatum. E. Pinnule. F. Indusium. G. A. concinnum, habit. H. A. digitatum, pinnules. 
Prado, J. \& Hirai, R.Y.
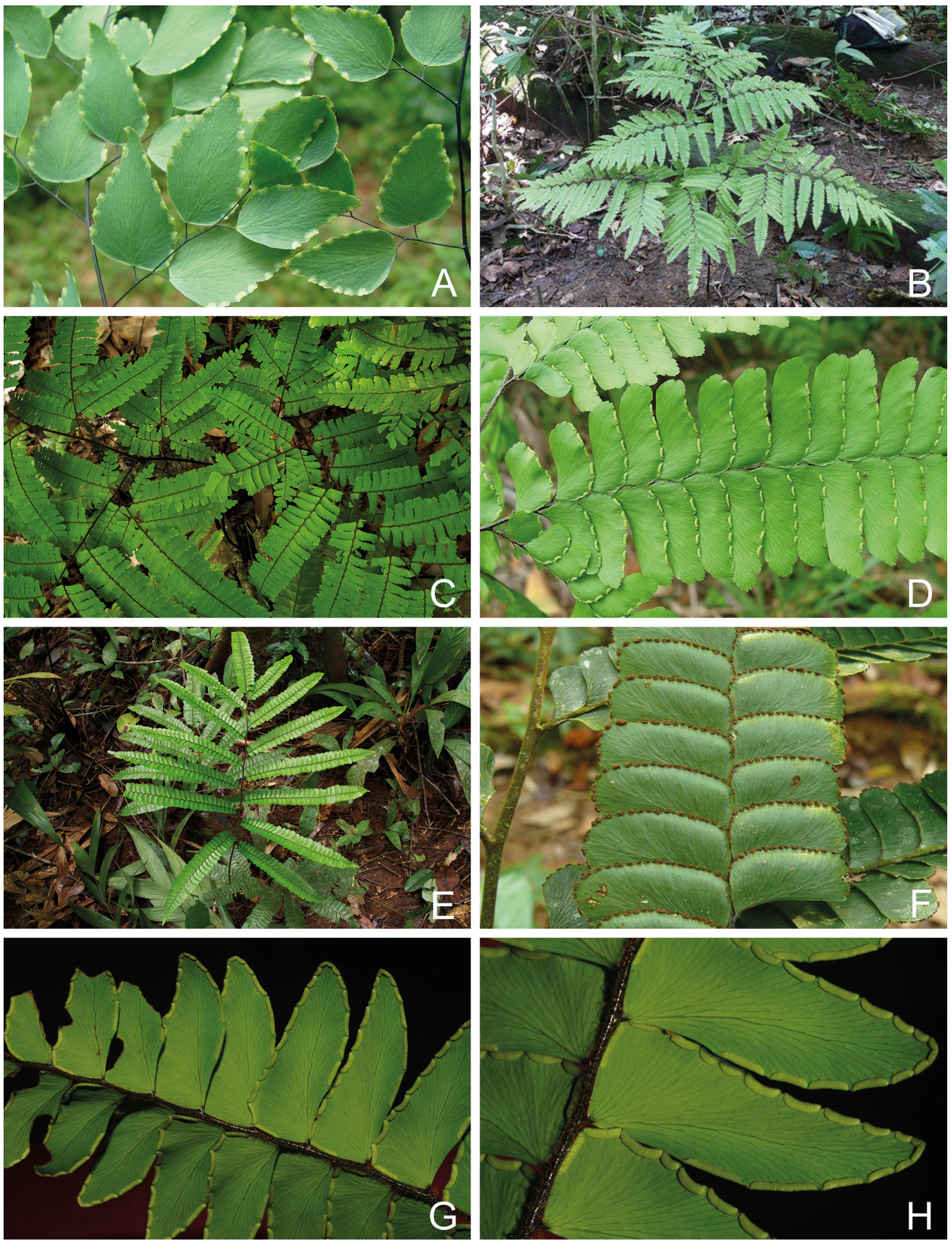

Figure 8. Adiantum species: A. A. subcordatum, pinnules abaxially. B-C. A. pectinatum, B. Habit. C. Pinnae (photos: GZ). D. A. abscissum, pinnules abaxially. E-F. A. tomentosum, E. Habit (photo: GM). F. Pinnules abaxially (photo: GZ). G-H. A. latifolium, G. Pinnules abaxially. H. Sori. 
Key to the Adiantum species in Brazil
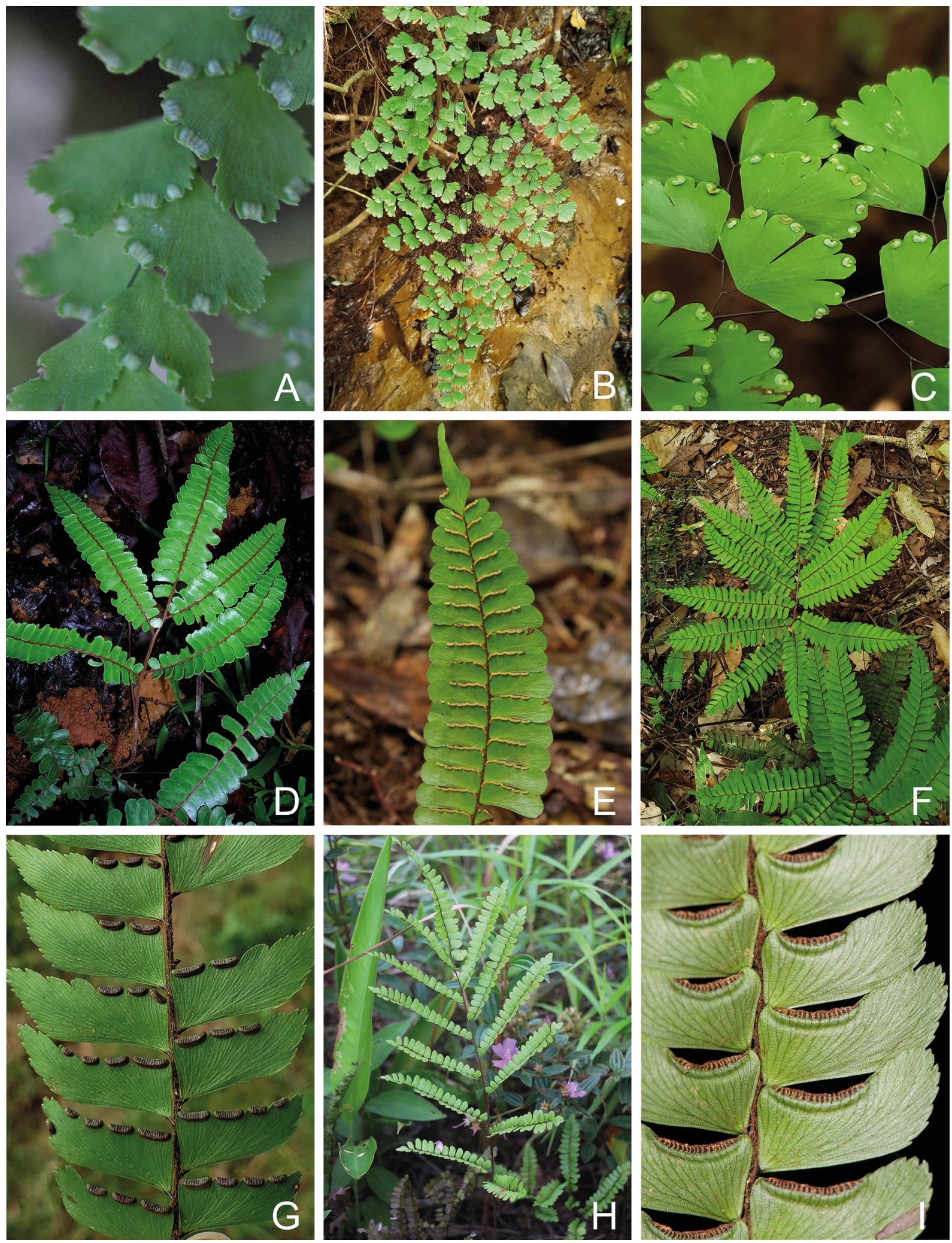

Figure 9. Adiantum species: A. A. capillus-veneris, sori (photo: MS). B-C. A. raddianum, B. Habit. C. Sori. D-E. A. paraense, D. Habit (photo: MB). E. Pinnules abaxially (photo: GM). F-G. A. intermedium, F. Habit. G. Sori. H. A. serratodentatum, habit (photo: MB). I. A. pulverulentum, sori. 


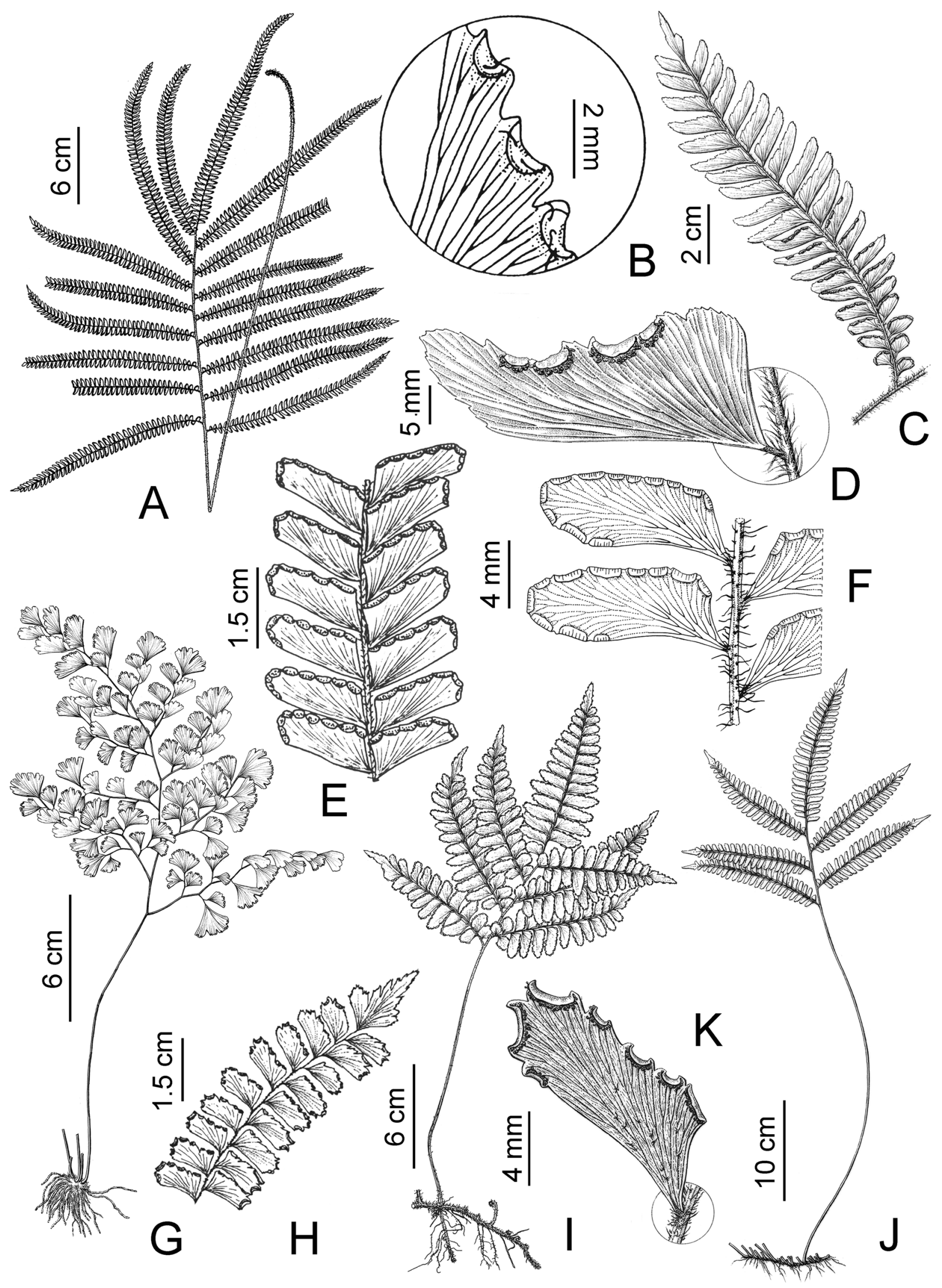

Figure 10. Adiantum species: A-B. A. dawsonii, A. Habit. B. Indusia. C-D. A. decoratum. C. Pinna. D. Indusia. E. A. diogoanum, pinnules. F. A. incertum, pinnules. G. A. lorentzii, habit. H. A. giganteum, pinnules. I. A. windischii, habit. J-K. A. nodosum, J. Habit. K. Indusia. 

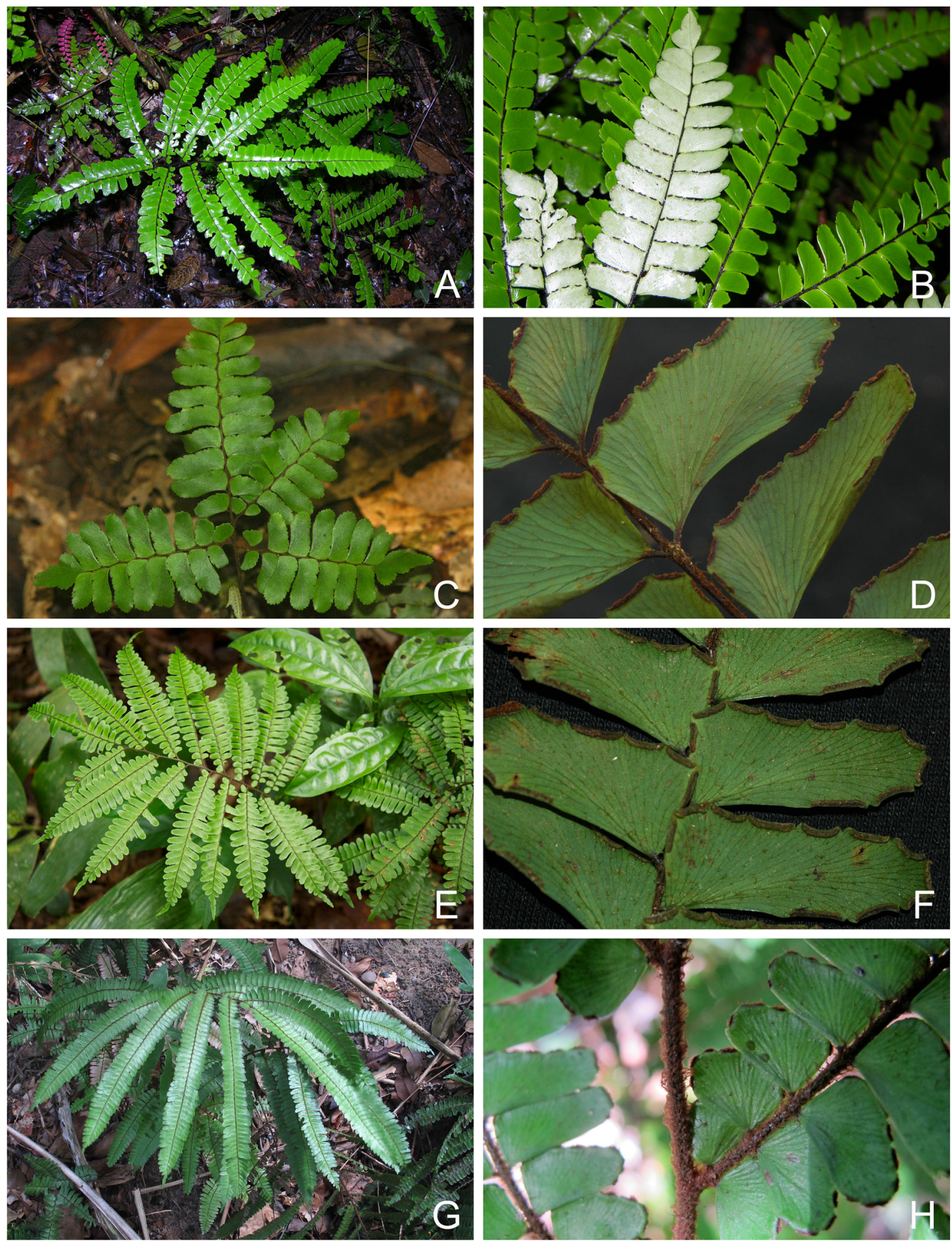

Figure 11. Adiantum species: A-B. A. discolor, A. Habit. B. Pinnae abaxially glaucous, adaxially green (photos: PL). C-D. A. humile, C. Habit. D. Sori (photos: GZ). E-F. A. terminatum, E. Habit (photo: HT). F. Sori (photo: GZ). G-H. A. multisorum, G. Habit. H. Rachis (photos: NS). 

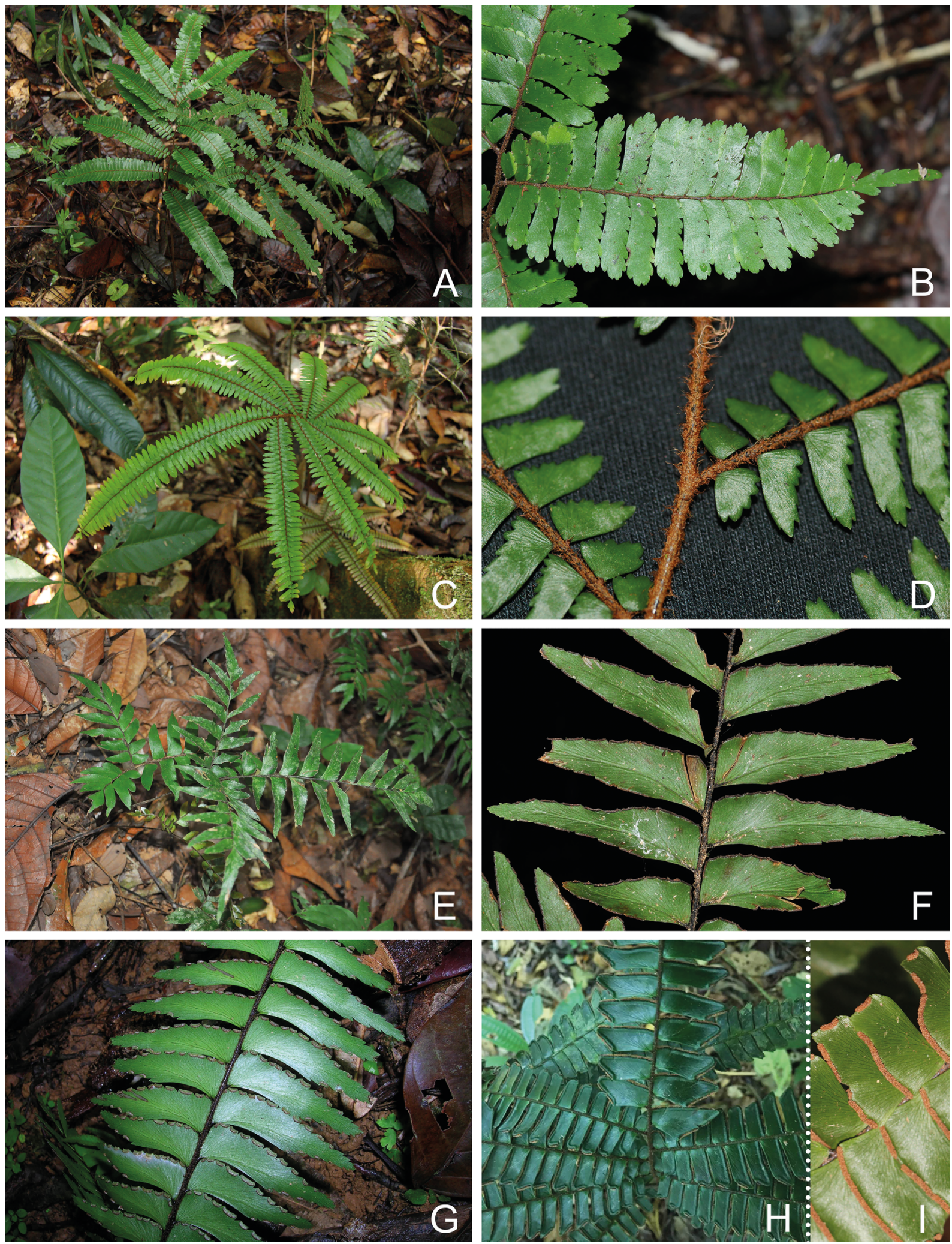

Figure 12. Adiantum species: A-B. A. cajennense, A. Habit. B. Sterile pinnules (photos: HT). C-D. A. cinnamomeum, C. Habit (photo: HT). D. Rachis and sterile pinnules (photo: GZ). E-F. A. argutum, E. Habit. F. Pinnae abaxially (photos: JN). G. A. tetraphyllum, habit (photo: MB). H-I. A. villosum, H. frond (photo: RM). I. sori (photo: MB). 


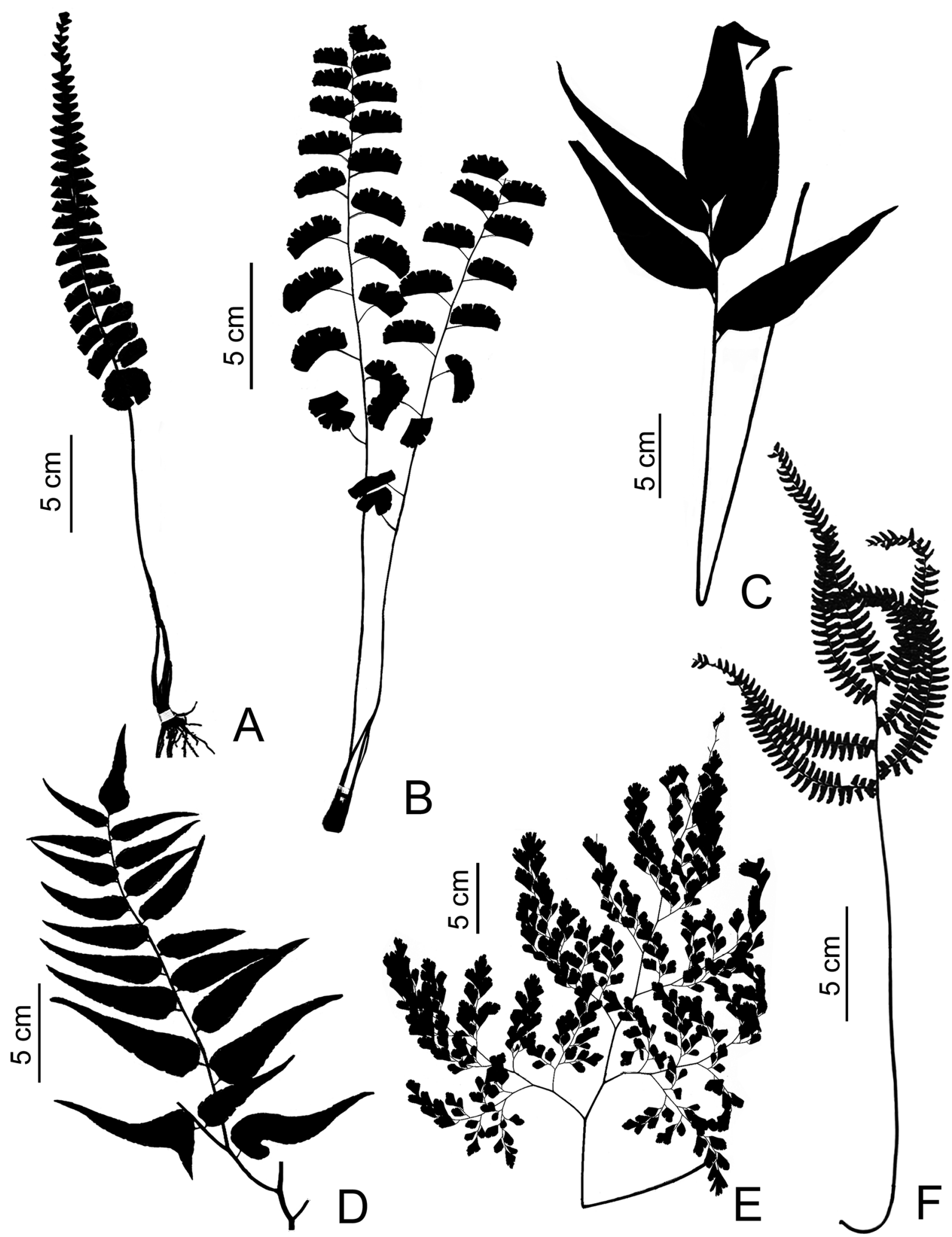

Figure 13. Adiantum species: A. Adiantum rhizophytum, habit (Glaziou 2287, K). B. A. philippense, habit (Bartlett \& Lasser 16842, US). C. A. phyllitidis, habit (Schomburgk 300, K). D. A. tetragonum, part of a frond (Wied s.n., BR). E. A. tenerum, frond (Liogier 28690, NY). F. A. gracile, frond (Claussen s.n., P). 
The treatment of Adiantum for Flora of Brazil (Prado \& Hirai, in preparation) resulted in the recognition of 65 species, 64 of them are native, and among them, one has a hybrid origin $(A$. $\mathrm{xmoranii)}$. This hybrid species does not appear in the key because of its unusual morphology, see more details about it in Prado (2005). And Adiantum peruvianum, a cultivated species, also does not appear in the key. Thus the following key distinguishes 63 native species.

Key to the Brazilian species of Adiantum

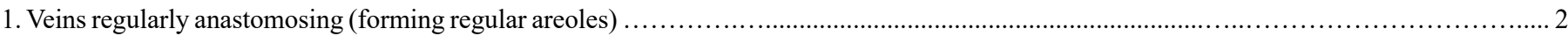

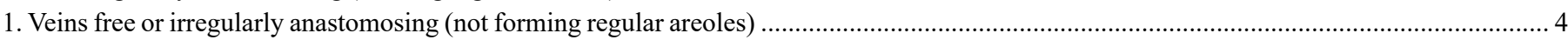

2. Rhizomes long-creeping; terminal pinna absent

A. diphyllum (Fée) Maxon* (Fig. 2A,B)

2. Rhizomes short-creeping; terminal pinna conform .... 3

3. Rachises with few scales and densely hairy; pinnules abaxially glabrous and adaxially sparsely setose along the basal and medial costae .............

Rachises only with hairs; pinnules glabrous on both surfaces

A. adiantoides (J.Sm.) C.Chr. (Fig. 2C,D)

4. Fronds 1-pinnate (rarely 2-pinnate at bases) A. leprieurii Hook. (Fig. 2E)

5. Pinnae or pinnules articulate

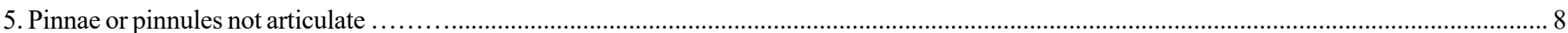

6. Pinnae dimidiately lunate or semi-rounded reniform, long-stalked, stalks $1-2 \mathrm{~cm}$ long ........................................... philippense L. (Fig. 13B)

6. Pinnae deltate, flabellate to rhombic, stalked, stalks up to $1 \mathrm{~cm}$ long

7. Sterile margins ciliate, the cilia ca. $2 \mathrm{~mm}$ long; indusia lobate-rounded

7. Sterile margins finely denticulate; indusia oblong to lunate

A. delicatulum Mart.* (Fig. 3A,B,C)

A. deflectens Mart. (Fig. 2F,G)

8. Rachises proliferous at apex

8. Rachises not proliferous at apex

9. Median pinnae incised to digitate; indusia lobate .

A. calcareum Gardner* (Fig. 3D,E,F)

9. Median pinnae entire to bi-tripartite flabellate; indusia oblong to lunate

A. rhizophytum Schrad.* (Fig. 13A)

10. Rachises glabrous

10. Rachises only with scales, or with scales and hairs, or only with hairs

11. Pinnae ovate-deltate, opposite, subsessile or short-stalked; sori 2 per pinna; indusia linear ...

A. macrophyllum Sw. (Fig. 3G,H)

11. Pinnae or pinnules oblong, ovate-lanceolate or suborbicular, alternate, short to long-stalked; sori more than 2 per pinna; indusia oblong or linear-arcuate

A. nudum A.R.Sm. (Fig. 4A)

12. Fronds 1-pinnate; pinnae dimidiate, oblong, short-stalked (stalk 1-2 mm long)

12. Fronds 1-pinnate (rarely 2-pinnate at base); pinnae or pinnules not dimidiate, ovate-lanceolate or suborbicular, long-stalked (stalk $0.5-2.5 \mathrm{~cm}$ long)

13. Rachises with scales and hairs

A. platyphyllum Sw. (Fig. 2H,I)

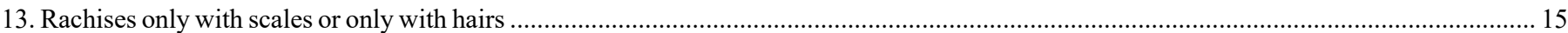

14. Pinnae or pinnules glabrous on both surfaces; idioblasts easily visible on adaxial blade surfaces, mostly parallel between veins, not visible abaxially; indusia linear-arcuate

A. petiolatum Desv. (Fig. 5A,B,C)

14. Pinnae or pinnules with filiform scales with pectinate bases on both surfaces; idioblasts conspicuous and oblique between veins adaxially and also visible abaxially; indusia oblong

A. obliquum Willd. (Fig. 5D,E)

15. Laminae with hairs on both surfaces, hairs $1-2 \mathrm{~mm}$ long

A. scalare R.M.Tryon (Fig. 4B)

15. Laminae with scales on both surfaces, scales with filiform apices and pectinate bases or laminae glabrous on both surfaces .......................... 16

16. Laminae glabrous on both surfaces

A. phyllitidis J.Sm. (Fig. 13C)

16. Laminae with scales on both surfaces

17. Veins free; rhizomes long-creeping, non-nodose

A. poeppigianum (Kuhn) Hieron. (Fig. 4D)

17. Veins anastomosing or irregularly anastomosing; rhizomes short-creeping and nodose

18. Pinnae or pinnules 6-9 times longer than wide, 4-5(-6) pairs, bases \pm equal-sided, rounded to slightly cuneate; veins anastomosing

A. dolosum Kunze (Fig. 5F,G)

18. Pinnae or pinnules 2-4 times longer than wide, 10-13 pairs, bases unequal-sided, rounded on acroscopic sides and cuneate on basiscopic sides; veins irregularly anastomosing but mostly free

A. lucidum (Cav.) Sw. (Fig. 5H,I)

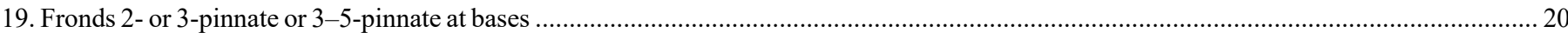

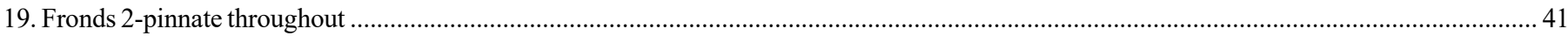

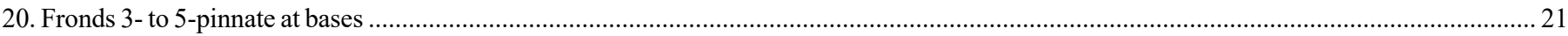

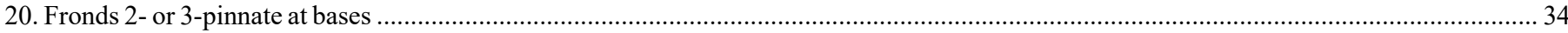

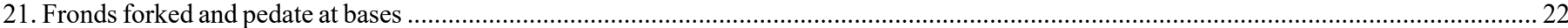


21. Fronds not forked at bases

22. Pinnules with glandular hairs on both surfaces or glabrous abaxially and puberulent along the costae adaxially ........................................... 23

22. Pinnules glabrous on both surfaces

23. Pinnules dimidiate; sori reniform or rounded

A. patens Willd. (Fig. 4E)

23. Pinnules deltate to lanceolate; sori linear, slightly arcuate

A. tetragonum Schrad.* (Fig. 13D)

24. Pinnules obovate to flabellate or pinnules dimidiate

24. Pinnules deltate, rhombic or subcordate to cordiform

25. Pinnules obovate to flabellate; rachises glabrous

A. pseudotinctum Hieron. (Fig. 6A, B)

25. Pinnules dimidiate; rachises with hairs

26. Stipes glabrous along median and distal portions

A. ornithopodum C.Presl ex Kuhn (Fig. 4F)

26. Stipes pubescent along median and distal portions, indument of scales and/or hairs

27

27. Rachises pubescent on both sides; apex of the segments rounded

A. lindsaeoides J.Prado \& R.Y.Hirai* (Fig. 4C)

27. Rachises glabrous abaxially and pubescent adaxially; apex of the segment long-acuminate to acute

28. Rachises with hairs adaxially, the hairs reddish

A. mynsseniae J.Prado* (Fig. 7A)

28. Rachises glabrous

A. papillosum Handro* (Fig. 4G)

29. Pinnules not articulate; deltate or irregularly rhombic

29. Pinnules articulate, rhombic to subcordate

A. pentadactylon Langsd. \& Fisch.* (Fig. 6C)

30. Pinnules articulate or tardily articulate, oblong to trapeziform or flabellate; rachises glabrous

A. subcordatum Sw.* (Fig. 8A)

30. Pinnules not articulate, dimidiate, orbicular, or flabellate, rhombic-cuneate; rachises pubescent or glabrous

31. Pinnules tardily articulate, oblong to trapeziform; sori orbicular to lunate

31. Pinnules articulate, flabellate; sori oblong .....

32. Rachises with hairs and some scales; pinnules dimidiate, abaxially with hairs, glabrous adaxially

32. Rachises glabrous; pinnules orbicular to flabellate or rhombic-cuneate, glabrous on both surfaces

33. Rhizomes long-creeping; pinnule bases usually symmetric; sori usually with yellow farina among sporangia; indusia membranaceous ......

A. poiretii Wikstr. (Fig. 7C,D)

33. Rhizomes short-creeping; pinnule bases usually asymmetric; sori without farina among sporangia; indusia rigid

A. sinuosum Gardner (Fig. 6D,E,F)

34. Pinnules articulate

A. glaucescens Klotzsch (Fig. 6G,H,I)

34. Pinnules not articulate 35

35. Rachises puberulent or with scales and hairs; pinnules digitate-flabellate or dimidiate

36

35. Rachises glabrous; pinnules entire to incised, orbicular, orbicular-cuneate, rhombic-cuneate or ovate to rhombic

36. Rachises puberulent; pinnules digitate-flabellate, puberulent on both surfaces

.38

36. Rachises with scales and hairs; pinnules dimidiate, glabrous on both surfaces

37. Indusia glabrous

37. Indusia with hairs

38. Veins ending into teeth at sterile margins of the pinnules

38. Veins ending between teeth at sterile margins of the pinnules

39. Proximal pinnules overlying rachises

A. mathewsianum Hook. (Fig. 7B)

A. tenerum Sw. (Fig. 13E)

A. pectinatum Desv. (Fig. 8B,C)

33

39. Proximal pinnules not overlying rachises

A. digitatum Hook. (Fig. 7H)

37

40. Pinnules copiously incised on distal margins to $2 / 3$ or more of pinnule length, pinnule bases cuneate and usually symmetric on proximal pinnules and asymmetric on distal pinnules

A. lorentzii Hieron. (Fig. 10G)

40. Pinnules entire or sometimes incised on distal margins to $1 / 2$ of the pinnule length, pinnule bases broadly cuneate and usually asymmetric .........

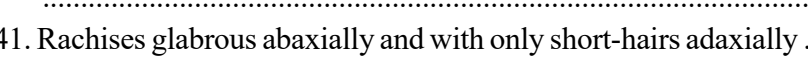

A. raddianum C.Presl (Fig. 9B,C)

41. Rachises only with scales or with scales and hairs

A. tomentosum Klotzsch (Fig. 8E,F)

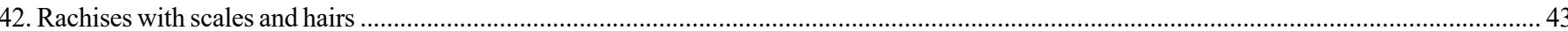

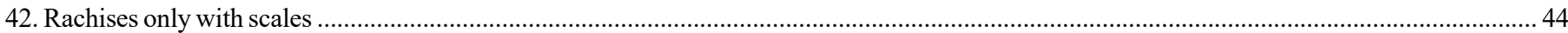

43. Rhizomes long-creeping; pinnules glabrous on both surfaces; indusia glabrous

43. Rhizomes short-creeping, nodose; pinnules abaxially with scales and glabrous adaxially; indusia bearing short-hairs

A. paraense Hieron. (Fig. 9D,E)

44. Rachises with one kind of scales (lanceolate to narrowly lanceolate with pectinate base or filiform-subulate) ................................................ 45

44. Rachises with two kinds of scales (hairlike and lanceolate with pectinate base or arachnoid and lanceolate with pectinate base) .................. 56

45. Pinnules conspicuously discolorous, light green on the abaxial surface and dark green above and veins not easily visible

A. discolor J.Prado* (Fig. 11A,B)

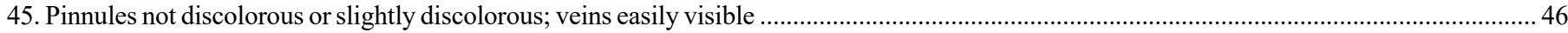

46. Pinnules glabrous on both surfaces or rarely with sparse scales abaxially ….......................................................................................... 47 
46. Pinnules with conspicuous hairs or scales at least on one surface

47.3 or 4 pairs of pinnae per frond; median pinnules trapeziform

A. decoratum Maxon \& Weath. (Fig. 10C,D)

47. 6-8 pairs of pinnae per frond; median pinnules falcate

A. intermedium Sw.* (Fig. 9F,G)

48. Pinnae 2-4 pairs per frond; pinnules abaxially with hairs ...

48. Pinnae 3-10 pairs per frond; pinnules abaxially with scales

49. Distal pinnules approximately half the size of largest pinnules; indusia glabrous .

A. humile Kunze (Fig. 11C,D)

49. Distal pinnules less than half the size of largest pinnules; indusia bearing hairs

A. terminatum Kunze ex Miq. (Fig. 11E,F)

50. Yellow, rounded glands present on abaxial surfaces of pinnules

A. dawsonii Lellinger \& J.Prado (Fig. 10A,B)

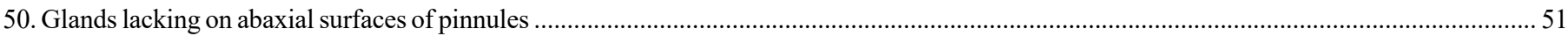

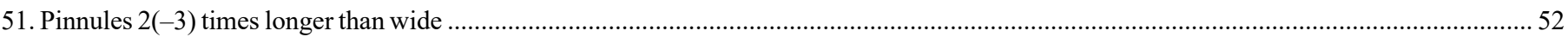

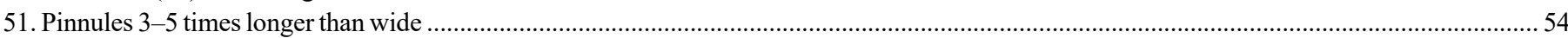

52. Pinnules with scales on both surfaces; indusia with scales .

A. multisorum Samp. (Fig. 11G,H)

52 . Pinnules glabrous adaxially or with scales only near the sori; indusia glabrous

53. 2-4(-6) pairs of pinnae per frond; $10-32$ pairs of pinnules per pinna

A. nodosum J.Prado et al. (Fig. 10J,K)

53. (3-)7-10 pairs of pinnae per frond; $27-43$ pairs of pinnules per pinna

A. gracile Fée* (Fig. 13F)

54. Pinnules 16-25 pairs per pinna; indusia bearing hairs

A. diogoanum Glaz. ex Baker (Fig. 10E)

54. Pinnules 30-45 pairs per pinna; indusia scaly

55. Sterile margins of the pinnules conspicuously incised and denticulate-serrate

55. Sterile margins of the pinnules serrate to biserrate

A. cajennense Willd. ex Klotzsch (Fig. 12A,B)

56. Rhizomes very long-creeping (cord-like)

A. cinnamomeum Lellinger \& J.Prado (Fig. 12C,D)

56. Rhizomes moderately long-creeping (not cord-like) or short-creeping

57. Pinnules abaxially with septate hairs, adaxially glabrous; indusia glabrous ...................................................... windischii J.Prado (Fig. 10I)

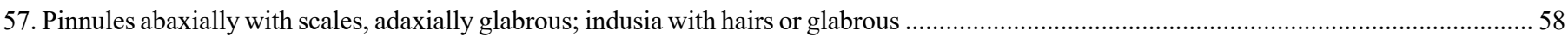

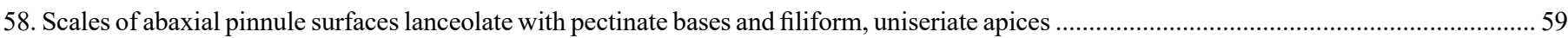

58. Scales of abaxial pinnule surfaces setiform; indusia glabrous

59. Sterile margin serrulate or entire (not incised) on the acroscopic and distal sides of the pinnules; indusia bearing hairs

A. serratodentatum Willd. (Fig. 9H)

59. Sterile margin incised, irregularly and distantly biserrate on the acroscopic and distal sides of the pinnules; indusia glabrous

A. giganteum J.Prado (Fig. 10H)

60. Pinnules 3-8 pairs per pinna, terminal pinnules larger than distal ones, broadly subrhombic, sterile margins biserrate

A. argutum Splitg. (Fig. 12E,F)

60. Pinnules 4-15 pairs per pinna, terminal pinnules reduced, narrowly subrhombic, sterile margins finely serrate .......A. incertum Lindm. (Fig. 10F)

61. Rachises adaxially mostly with filiform scales (hairlike) and abaxially with lanceolate scales with pectinate bases; indusia oblong, with hairs, hairs reddish brown

A. tetraphyllum Willd. (Fig. 12G)

61. Rachises on both sides mostly with arachnoid scales and some lanceolate scales with pectinate bases; indusia linear, lunate, glabrous or with brown hairs

62. One indusia per pinnule

A. pulverulentum L. (Fig. 9I)

62. Two or three indusia per pinnule

A. villosum L. (Fig. 12H)

\section{Discussion}

As already commented here, 16 species of Adiantum in Brazil are endemic and have restricted area of occurrence compared to the species widely distributed. Among those with very narrow distribution are: Adiantum diphyllum, Figure 2A, B and A. discolor, 11A, B (Brazilian Atlantic Rainforest: Bahia State; Sundue \& Prado 2006; Prado 2000, respectively), A. lindsaeoides, Figure 4C (Brazilian Atlantic Rainforest: Bahia and Espírito Santo States; Prado \& Hirai 2013), A. tetragonum Figure 13D (Brazilian Atlantic Rainforest: Bahia and Minas Gerais States; Prado \& Sundue 2005).

Adiantum adiantoides, Figure 2C, D, is not restrict to Brazil, but has its occurrence only in the Brazilian Amazon Forest of the states of Pará, Amazonas, and Amapá (Sundue \& Prado 2006).

Among those endemic species to Brazil, some have been recently described as Adiantum lindsaeoides, Figure 4C, Prado \& Hirai (2013) or were described in the last 20 years: A. discolor, Figure 11A, B, Prado (2000), A. mynsseniae, Figure 7A, Prado (2003, 2004), and $A$. xmoranii (Prado 2005).

Among the other species recently described and that are not restricted to Brazil are: Adiantum dawsonii, Figure 10A, B and $A$. cinnamomeum, Figure 12C, D, Lellinger \& Prado (2001), A. giganteum, Figure 10H, Prado (2001), A. windischii, Figure 10I, Prado (2005), and A. nodosum, Figure 10J, K, Prado et al. (2017b).

The key and data here presented are only the first steps to approach the diversity of Adiantum in Brazil. Based on our experience with this interesting and difficult group of plants, certainly, there are more species to be described. During our investigations, we observed some specimens that could be hybrids between known species, but describing these gatherings as distinct taxa is too premature. More fieldwork is necessary to locate more individuals and better study their biology. 
We hope that the present key can be a good first step in recognizing undescribed species for our rich flora.

\section{Acknowledgements}

The authors thank all cited persons in the material and methods for sharing the photos for publication. Michel Boudrie for your suggestions to improve the text, especially the key. JP thanks CNPq by the grants n. 300843/1993-3 and n. 303875/2016-0 to realize this work. RYH thanks the Instituto de Botânica (IBt) for all support to develop this work and FAPESP for the grant n. 2011/07164-3.

\section{Author Contributions}

Jefferson Prado: Substantial contribution to the concept and design of the study, contribution to data analysis and interpretation, contribution to manuscript preparation, and contribution to critical revision, adding intellectual content.

Regina Y. Hirai: Substantial contribution to the concept and design of the study, contribution to data collection, contribution to data analysis and interpretation, and contribution to manuscript preparation (text + illustrations).

\section{Conflicts of Interest}

The authors declare that they have no conflict of interest related to the publication of this manuscript.

\section{References}

HIRAI, R.Y. \& PRADO, J. 2019. Neotropical species of the Adiantum raddianum group (Pteridaceae). Willdenowia 49(3): 295-317.

HIRAI R.Y., SCHUETTPELZ, E., HUIET, L., PRYER, K.M., SMITH, A.R. \& PRADO, J. 2016. Phylogeny and relationships of the neotropical Adiantum raddianum group (Pteridaceae). Taxon 65(6): 1225-1235.

HUIET, L., LI, F.-W., KAO, T.-T., PRADO, J., SMITH, A.R., SCHUETTPELZ, E. \& PRYER, K.M. 2018. A worldwide phylogeny of Adiantum (Pteridaceae) reveals remarkable convergent evolution in leaf blade architecture. Taxon 67(3): 488-502.

LELLINGER, D.B. 2002. A Modern Multilingual Glossary for Taxonomic Pteridology. Pteridologia 3A. Washington, American Fern Society.

LELLINGER, D.B. \& PRADO, J. 2001. The group of Adiantum gracile in Brazil and environs. Amer. Fern J. 91(1): 1-8.
PICHI SERMOLLI, R.E.G. 1996. Authors of scientific names in Pteridophyta. Royal Botanic Gardens, Kew.

PPG I. 2016. A community-derived classification for extant lycophytes and ferns. J. Syst. Evol. 54(6): 563-603.

PRADO, J. 2000. A new species of Adiantum (Pteridaceae) from Bahia, Brazil. Brittonia 52(2): 210-212.

PRADO, J. 2001. Adiantum giganteum (Pteridaceae: Pteridophyta), a new maidenhair fern from Amazonia, Brazil. Fern Gaz. 16(5): 209-212.

PRADO, J. 2003. New species in Adiantum from Brazil. Amer. Fern J. 93(2): $76-80$.

PRADO, J. 2004. Nomenclatural corrections in Adiantum. Amer. Fern J. 94(2): 112.

PRADO, J. 2005. A new species and hybrid in Adiantum (Pteridaceae) from South America. Kew Bull. 60(1): 117-121.

PRADO, J. 2015. Pteridaceae in Lista de Espécies da Flora do Brasil. Jardim Botânico do Rio de Janeiro. http://floradobrasil.jbrj.gov.br/jabot/ floradobrasil/FB91951 (last access in 08/01/2018).

PRADO, J. \& HIRAI, R.Y. 2013. Adiantum lindsaeoides (Pteridaceae), a New Fern Species from the Atlantic Rain Forest, Brazil. Syst. Bot. 38(1): 28-31.

PRADO, J. \& SUNDUE, M.A. 2005. Typification and identity of Adiantum tetragonum (Pteridaceae). Amer. Fern J. 95(3): 89-93.

PRADO, J. \& SYLVESTRE, L.S. 2010. As samambaias e licófitas do Brasil. In Catálogo de plantas e fungos do Brasil (R.C. Forzza, J.F.A. Baumgratz, C.E.M. Bicudo, D. Canhos, A.A. Carvalho Jr., A. Costa, D.P. Costa, M. Hopkins, P.M. Leitman, L.G. Lohmann, E.M. Lughadha, L.C. Maia, G. Martinelli, M. Menezes, M.P. Morim, M. Nadruz, A.L. Peixoto, J.R. Pirani, J. Prado, L.P. Queiroz, V.C. Souza, J.R. Stehmann, L.S. Sylvestre, B.M.T. Walter \& D.C. Zappi, orgs.). Jardim Botânico do Rio de Janeiro, Rio de Janeiro, v. 1, p. 69-74.

PRADO, J., HIRAI, R.Y. \& MORAN, R.C. 2017a. Fern and lycophyte flora of Acre state, Brazil. Biota Neotropica 17(4): e20170369. https://doi. org/10.1590/1676-0611-bn-2017-0369 (last access in 22/10/2020).

PRADO, J., HIRAI, R.Y., SMITH, A.R. \& TUOMISTO, H. 2017b. Novelties in Adiantum (Pteridaceae) from South America. Willdenowia 47(3): 237-242.

PRADO, J., SYLVESTRE, L.S., LABIAK, P.H., WINDISCH, P.G., SALINO, A., BARROS, I.C.L., HIRAI, R.Y., ALMEIDA, T.E., SANTIAGO, A.C.P., KIELING-RUBIO, M.A., PEREIRA,A.F.N.,ØLLGAARD, B., RAMOS, C.G.V., MICKEL, J.T., DITTRICH, V.A.O., MYNSSEN, C.M., SCHWARTSBURD, P.B., CONDACK, J.P.S., PEREIRA, J.B.S. \& MATOS, F.B. 2015. Diversity of ferns and lycophytes in Brazil. Rodriguésia 66(4): 1073-1083.

SUNDUE, M.A. \& PRADO, J. 2006. Adiantum diphyllum, a rare and endemic species of Bahia State, Brazil and its close relatives. Brittonia 57(2): 123-128.

Received: 27/08/2020

Revised: 15/10/2020

Accepted: 19/10/2020

Published online: 20/01/2021 